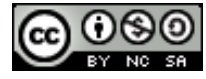

https://doi.org/10.31743/abmk.11785

KS. WŁADYSŁAW P. WLAŹLAK* - RZESZÓW

\title{
ZMIANY PERSONALNE W ORGANIZACJI ADMINISTRACJI I SĄDOWNICTWIE DIECEZJI KUJAWSKO-KALISKIEJ
} (1918-1925)

\begin{abstract}
Streszczenie
Problematyka zmian personalnych $\mathrm{w}$ administracji i sądownictwie diecezji kujawsko-kaliskiej w latach 1918-1925, była uwarunkowana kilkoma czynnikami. Przede wszyskim doszło do zmian w prawodawstwie kościelnym. Nowy Kodeks Prawa Kanonicznego, który zaczął obowiązywać w 1918 r. oddzielał władzę administracyjną od sądowniczej. W tymże roku biskup kujawsko-kaliski ustanowił Kurię Biskupią we Włocławku dla prowadzenia spraw administracyjnych, zaś dla prowadzenia spraw sądowych ustanowił Trybunał Generalny we Włocławsku oraz Trybunał Pomocniczy w Częstochowie i Kaliszu. W miejsce dawnego oficjalatu włocławskiego ustanowił wikariat generalny włocławski, oficjalat kaliski został wikariatem, zaś oficjalat piotrkowski przemianował na wikariat częstochowski. We Włocławku rezydował wikariusz generalny dla całej diecezji, którym był biskup pomocniczy. Nadto w stolicy diecezji urzędował ks. S. Chodyński, któremu podlegał wikariat włocławski, był jednocześnie oficjałem Trybunału Włocławskiego. Wiceoficjałem tegoż Trybunału był bp W.S. Owczarek, który następnie objął urząd oficjała. $\mathrm{Z}$ kolei wikariuszem generalnym i wiceoficjałem w Trybunale Częstochowskim został bp W.P. Krynicki, zaś wikariuszem generalnym i wiceoficjałem w Trybunale Kaliskim był ks. J.N. Sobczyński. Należy zauważyć, że w kurii byli zatrudnieni kanclerz, konsultorzy, radcowie, sekretarze, skarbnik, archiwariusz, architekci, członkowie różnych komisji, cenzorzy ksiąg religijnych i wizytatorzy nauki religii. Piastujący powyższe stanowiska duchowni pracowali również w sądzie, a większość z nich stanowiła elitę duchowieństwa, które było wykształcone w zagranicznych uczelniach. Władza diecezjalna doceniała ich zaangażowanie, czego wyrazem były nadawane im godności kościelne. Wielu $\mathrm{z}$ nich parało się pracą naukową. Ten skład obsady personalnej uległ zmianie
\end{abstract}

* Ks. Władysław P. Wlaźlak - dr hab. prof. UR, Instytut Nauk Prawnych, Uniwersytet Rzeszowski; e-mail: wwlazlak@ur.edu.pl

https://orcid.org/0000-0001-5293-8736 
w 1925 r., kiedy diecezja kujawsko-kaliska utraciła wikariat częstochowski na rzecz nowo utworzonej diecezji.

Słowa kluczowe: diecezja kujawsko-kaliska; Włocławek; diecezja włocławska; kanclerz kurii; konsystorz; Kuria Biskupia; Sąd Biskupi

\section{Wstęp}

Po utworzeniu Królestwa Polskiego doszło do reorganzacji administracji kościelnej. Na mocy bulli Ex imposita nobis z 30 czerwca 1818 r. diecezja włocławska otrzymała nowe terytorium. W miejsce utraconego Pomorza, które znalazło się w Prusach, diecezja otrzymała obszary na południe od Włocławka sięgające aż po Częstochowę. Bulla papieska zmieniła dotychczasową nazwę diecezji kujawsko -pomorskiej na diecezję włocławską czyli kaliską, jednak powszechnie nazwano ją kujawsko-kaliską ${ }^{1}$. W tym okresie doszło do likwidacji archidiakonatów, zaś jej funkcję przejęły oficjalaty. $Z$ obszaru dawnej diecezji pozostał oficjalat kujawski przemianowany następnie na włocławski, zarządzony przez Konsystorz Generalny Kujawski nazywany z czasem Włocławkim. Na przyłączonym terytorium $\mathrm{z}$ archidiecezji gnieźnieńskiej funkcjonował oficjalat okręgowy kaliski, który został przemianowany na generalny, zarządzany przez Konsystorz Generalny w Kaliszu. Funkcjonowanie dwóch konsystorzy tej rangi na terenie diecezji było ewenementem, co było spowodowane faktem rezydowania biskupa w Kaliszu, a nie we Włocławku. Konsystorzowi Kaliskiemu podlegały dwa konsytorze okręgowe: piotrkowski nowo erygowny i wieluński funkcjonujący jeszcze w okresie gnieźnieńskim. Na wspomnianym terytorium istniał jeszcze Konsystorz Okręgowy w Uniejowie, który jednak nie wznowił swojej działalności w diecezji kujawsko-kaliskiej. W roku 1823 zlikwidowano Konsytorz Wieluński, zaś podległe mu dekanaty krzepicki i wieluński podporządkowano oficjałowi piotrkowskiemu, a dekanat wieruszowski przyłączono do oficjalatu kaliskiego. Kolejną reorganizację przeprowadzono w 1885 r., kiedy zredukowano Konsytorz Kaliski do rangi okręgowego i podporządkowano go Konsystorzowi Generalnemu Włocławskiemu. Do pewnych zmian w strukturze terytorialnej oficjalatów doszło nieco wcześniej bo w 1868 r., kiedy pod naciskiem władz carskich doszło do ustanowienia tzw. dużych dekanatów dopasowanych do granic powiatów. Dawny dekanat wieluński i znaczna część dekanatu krzepickiego weszły w skład powiatu wieluńskiego, który jako dekanat wieluński przyłączono do oficjalatu kaliskiego. Jako rekompensatę oficjalat piotrkowski otrzymał powiat łaski, gdzie utworzono dekanat o tej nazwie. Stan ów nie uległ zmianie do końca pierwszej wojny światowej²

Do nowych rozwiązań w administracji i sądownictwie diecezji doszło w wyniku zmiany prawodawstwa kościelnego. Nowy Kodeks Prawa Kanonicznego promulgowany bullą Providentissime Mater Ecclesia w dniu 27 maja 1917 r. przez

${ }^{1}$ Papiestwo wobec sprawy polskiej 1772-1864, wybór źródeł opr. O. Beiersdorf, Wrocław 1960, s. 271-283.

2 W. Wlaźlak, Sądownictwo kościelne w diecezji włocławskiej czyli kaliskiej (1819-1918), „Czasopismo Prawno-Historyczne”, 54 (2002) z. 1, s. 365 n. 
Benedykta XV zaczął obowiązywać od 19 maja 1918 r. $^{3}$ Oddzielił on władzę administracyjną i sądowniczą $\mathrm{w}$ dawnych konsystorzach generalnych lub okręgowych. Dla sprawowania pierwszej z nich powstała Kuria Biskupia zwana też diecezjalną, a dla sprawowania tej drugiej utworzono Sąd Biskupi. W związku ze zmianami w prawie kanonicznym biskup kujawsko-kaliski Stanisław K. Zdzitowiecki uformował Kurię Biskupią we Włocławku dla prowadzenia spraw administracyjnych diecezji. Z kolei dla rozstrzygania spraw sądowych w diecezji utworzył Sąd Biskupi, czyli Trybunał Generalny we Włocławku oraz podległe mu: Trybunał Pomocniczy w Częstochowie i Trybunał Pomocniczy w Kaliszu ${ }^{4}$. Wszystkim tym działaniom sprzyjała sytuacja polityczna odradzającej się Polski, w której reaktywowano dawne dekanaty o mniejszej liczbie parafii, sprzyjające bardziej efektywnemu prowadzeniu działalności duszpasterskiej. Z tego powo$\mathrm{du} \mathrm{w}$ artykule zaprezentowano strukturę nowego podziału terytorialnego diecezji kujawsko-kaliskiej, a następnie działające na jej obszarze instytucje diecezjalne. W szczególny sposób odniesiono się do zmian w obsadzie personalnej administracji i sądownictwie.

\section{Wikariaty generalne}

W miejsce dawnych jednostek terytorialnych, czyli oficjalatów: włocławskiego, kaliskiego i piotrkowskiego powołano nowe okręgi, czyli wikariaty generalne. Wikariat włocławski obejmował dekanaty: brzeski, chodecki, nieszawski, piotrkowski, radziejowski i włocławski, które znajdowały się na terytorium powiatu nieszawskiego, płockiego i włocławskiego. Wikariat częstochowski nawiązywał do dawnego oficjalatu piotrkowskiego i obejmował dekanaty: bełchatowski, brzeźnicki, częstochowski, gidelski, gorzkowicki, kłobucki, łaski, mstowski, pabianicki, piotrkowski, radomszczański, tuszyński, widawski, które znajdowały się na terytorium powiatu częstochowskiego, łaskiego, łódzkiego, piotrkowskiego i radomszczańskiego. Wikariat kaliski obejmował dekanaty: izbicki, kaliski, kolski, koniński, koźminecki, sieradzki, słupecki, stawiszyński, stawski, szadkowski, tuliszkowski, turecki, uniejowski, warcki, zagórowski, złoczewski, które znajdowały się na terenie powiatu kaliskiego, kolskiego, konińskiego, łęczyckiego, sieradzkiego i słupeckiego. Według schematyzmów diecezjalnych dekanaty: bolesławiecki, praszkowski, wieluński i wieruszowski, które znajdowały się na terytorium powiatu wieluńskiego w 1923 r. zostały przeniesione z wikariatu kaliskiego do częstochowskiego ${ }^{5}$. Nie jest to zgodne z prawdą, gdyż bp S.K. Zdzitowiecki już w dniu 20 listopada 1918 r. przydzielił dekanaty z powiatu wieluńskie-

${ }^{3}$ Codex Iuris Canonici. Pii X Pontificis Maximi iussu digestus. Benedicti Papae XV auctoritate promulgatus, red. P. Gasparri, Romae 1934, (dalej: CIC).

${ }^{4}$ J. Dębiński, Duchowieństwo rzymskokatolickie diecezji włocławskiej w latach 1918-1939, Toruń 2010, s. 232-233.

${ }^{5}$ Catalogus ecclesiarum et utriusque cleri, tam saecularis quam regularis, dioecesis Vladislaviensis seu Calissiensis pro anno Domini 1923, Wladislaviae 1923, s. 20-21; Catalogus ecclesiarum et utriusque cleri, tam saecularis quam regularis, dioecesis Vladislaviensis seu Calissiensis pro anno Domini 1924, Wladislaviae 1924, s. 28-29. 
go z dawnego oficjalatu kaliskiego do wikariatu częstochowskiego ${ }^{6}$. Jeszcze przez kilka lat schematyzmy diecezjalne powielały ten błąd, używając nadto dawnego określenia oficjalaty dla nowo powstałych okręgów, czyli wikariatów? ${ }^{7}$ Podsumowując strukturę administracyjno-terytorialną wikariatów należy zauważyć, iż najmniejszym był wikariat włocławski, gdyż w jego skład wchodziły 52 parafie. Wikariat częstochowski obejmował 149 parafii, zaś w skład wikariatu kaliskiego wchodziły 153 parafie ${ }^{8}$. Ów stan struktury administracyjno-terytorialnej obowiązywał do 28 października 1925 r., kiedy południowe obszary diecezji kujawsko -kaliskiej na mocy bulli Vixdum Poloniae unitas ${ }^{9}$ zostały przyłączone do nowo powstałej diecezji częstochowskiej. Na dotychczasowej strukturze administracyjnej Trybunału Pomocniczego w Częstochowie powstała Kuria Biskupia nowej diecezji ${ }^{10}$.

\section{Kuria Biskupia}

Wraz ze zmianami w strukturze administracyjno-terytorialnej diecezji, ordynariusz w dniach 20-21 listopada 1918 r. dokonał obsady personalnej Kurii Biskupiej we Włocławku. Wprawdzie nowy Kodeks Prawa Kanonicznego zakładał, że powinien być jeden wikariusz generalny, to jednak dopuszczał wyjątki, z czego skorzystał miejscowy ordynariusz. Zgodnie z tym zapisem, biskup kujawsko-kaliski udzielił nowo mianowanym wikariuszom generalnym władzę rozpatrywania wszystkich przypadków określonych w prawie kościelnym, które nie wymagały specjalnego mandatu ordynariusza. Wyłączone $\mathrm{z}$ ich gestii były m.in. inkardynacja lub ekskardynacja duchownych, erygowanie stowarzyszeń kościelnych, rozgrzeszanie z niektórych przewinień, wymierzanie kar i inne. Rządca diecezji zaznaczył, iż nie będzie można zwracać się do niego z apelacją od ich decyzji. Otrzymali oni również władzę nadawania zgodnie z prawem kanonicznym kościelnych beneficjów, przeprowadzania wizytacji w diecezji i przydzielania niektórym proboszczom koadiutorów parochis impeditis. Nadto bp S.K. Zdzitowiecki udzielił wikariuszom generalnym władzy, o której nie wspominało prawodawstwo kościelne, czyli ustanawianie w wyjątkowych sytuacjach swojego zastępcy $^{11}$.

${ }^{6}$ S. Zdzitowiecki, Nominacja wikariuszów generalnych, „Kronika Diecezji Kujawsko-Kaliskiej” (dalej: KDKK), 12 (1918) nr 12, s. 332.

${ }^{7}$ Analogiczne dane zawierają schematyzmy aż do 1923 r. - Catalogus ecclesiarum et utriusque cleri, tam saecularis quam regularis, dioecesis Vladislaviensis seu Calissiensis pro anno Domini 1919, Wladislaviae 1919, s. 15-17.

${ }^{8}$ Diecezja włocławska 2000, Włocławek 2001, s. 30-31.

${ }^{9}$ Bulla Vixdum Poloniae unitas, „Acta Apostolicae Sedis”, 17 (1925), s. 521-528; T. Włodarczyk, Konkordaty. Zarys historii z uwzględnieniem XX wieku, wyd. 2, Warszawa 1986, s. 317-320.

${ }^{10}$ W. Wlaźlak, Judicium Succursale Czenstochoviensis (1918-1925), „Gubernaculum et Administratio. Zeszyty Naukowe Instytutu Administracji Wyższej Szkoły Pedagogicznej w Częstochowie”, (2002) z. 2, s. 13-17.

${ }^{11}$ CIC, can. 113, 152, 357, 455, 477, 686, 893, 958, 1155, 1162, 1283, 1285, 1414, 1423, 1432 , 1487, 2020, 2220, 2314; J. Dębiński, Duchowieństwo rzymskokatolickie, s. 232-233. 
Wikariuszem generalnym dla całej diecezji w dniu 21 listopada 1918 r. został bp Wojciech S. Owczarek, który rezydował we Włocławku ${ }^{12}$. Do pracy na tym stanowisku był dobrze przygotowany. Odbył studia specjalistyczne w Akademii Duchownej w Petersburgu, gdzie w 1901 r. uzyskał stopień magistra teologii. W rok po powrocie ze studiów, rozpoczął pracę w sądownictwie i jako wykładowca Seminarium Duchownego we Włocławku. Niebawem doceniano jego zaangażowanie, gdyż otrzymał godności kościelne: w 1912 r. kanonika włocławskiego, w 1919 r. archidiakona i w 1928 r. dziekana tejże kapituły. Najważniejszym była jednak nominacja z dnia 29 lipca 1918 r. na biskupa pomocniczego diecezji kujawsko-kaliskiej. W roku 1923 uzyskał doktorat honorowy prawa kanonicznego, nadany przez Watykańską Kongregację Seminariów i Studiów Uniwersyteckich w Rzymie. W latach 1928-1929 był wikariuszem kapitulnym diecezji włocławskiej ${ }^{13}$. Drugim wikariuszem generalnym we Włocławku został ks. Stanisław Chodyński, jednak funkcji tej długo nie pełnił, gdyż zmarł w niespełna rok później ${ }^{14}$. Biskup S.K. Zdzitowiecki mianując wikariuszy generalnych dokonał podziału diecezji na okręgi, które zostały nazwane wikariatami generalnymi. Wikariuszem generalnym w Częstochowie w 1918 r. został biskup pomocniczy kujawsko-kaliski Władysław P. Krynicki. Stanowisko wikariusza generalnego w Kaliszu po śmierci ks. S. Chodyńskiego w 1919 r. objął ks. Jan N. Sobczyński. Taki stan zachował się do 1925 r., kiedy doszło do ogłoszenia bulli papieskiej reorganizującej diecezje polskie, a tym samym zmiany w strukturze terytorialnej diecezji kujawsko-kaliskiej ${ }^{15}$.

Reorganizując zarząd diecezją, biskup ustanowił nowy urząd, czyli radców aktualnych Kurii Biskupiej, którego nie przewidywał nowy Kodeks Prawa Kanonicznego. Pomagali oni w administrowaniu dobrami kościelnymi diecezji. Wśród nich był ks. Feliks Mikulski, który funkcje tę pełnił w latach 1918-1930. Posiadał doświadczenie kurialne, co doceniła władza diecezjalna, gdyż w 1915 r. został kanonikiem włocławskim, w 1929 r. scholastykiem tej kapituły. Biskup włocławski W.P. Krynicki mianował go zastępcą wikariusza generalnego ${ }^{16}$. Innym wybitnym kapłanem był ks. Piotr Czapla, który funkcje radcy pełnił w latach 19181928. Do tej pracy był dobrze przygotowany, gdyż odbył studia specjalistyczne na Uniwersytecie w Innsbrucku, gdzie w 1904 r. uzyskał stopień doktora teologii. Po powrocie do diecezji został ustanowiony wykładowcą włocławskiego Seminarium Duchownego. W roku 1918 mianowano go kanonikiem włocławskim, gdzie sprawował też obowiązki archiwariusza. Jego zaangażowanie dostrzegły władze kościelne, gdyż w 1922 r. odznaczono go godnością prałata domowego. Z kolei

${ }^{12}$ S. Zdzitowiecki, Nominacja wikariuszów, s. 331-332.

${ }^{13}$ Archiwum Diecezji Włocławskiej (dalej: ADW), Akta personalne bp. Wojciecha Owczarka, t. 1-2, sygn. 238a, passim; K. Rulka, Owczarek Wojciech Stanisław bp, w: Encyklopedia Katolicka (dalej: EK), t. 14, Lublin 2010, kol. 1048-1049; J. Dębiński, Duchowieństwo rzymskokatolickie, s. 240,724 .

${ }^{14}$ S. Librowski, Chodyński Stanistaw ks., EK, t. 3, Lublin 1985, kol. 207-208.

${ }^{15}$ J. Dębiński, Duchowieństwo rzymskokatolickie, s. 232-233; Diecezja włocławska, s. 30.

${ }^{16}$ J. Szymak, Ś.p. ks. Feliks Mikulski, KDKK, 27 (1933) nr 6, s. 181-184; Diecezja włocławska, s. 90,318 . 
w latach 1925-1928 był rektorem seminarium, co było zwieńczeniem jego kariery kościelnej ${ }^{17}$.

Równie wybitną postacią wśród radców był ks. Rudolf Filipski, który funkcję tę pełnił w latach 1918-1930. Zdobył on gruntowne wykształcenie. Studia specjalistyczne odbył w Akademii Duchownej w Petersburgu, gdzie w 1885 r. uzyskał stopień magistra teologii. Dla uzupełnienia studiów przebywał na Uniwersytecie we Fryburgu Szwajcarskim, Rzymie i Innsbrucku. W roku 1908 został wykładowcą włocławskiego Seminarium Duchownego i kanonikiem włocławskim, a następnie kanonikiem honorowym sandomierskim ${ }^{18}$. Innym duchownym będącym radcą kurii był ks. Wacław Kwarciański, który funkcje tę pełnił w latach 1918-1920. Studia specjalistyczne odbył w Uniwersytecie Gregoriańskim w Rzymie, gdzie w 1890 r. uzyskał stopień doktora prawa kanonicznego. Następnie przez wiele lat był zaangażowany w szkolnictwie kaliskim i włocławskim. W uznaniu zasług, w 1919 r. został mianowany kanonikiem włocławskim, zaś w 1933 r. awansowany na scholastyka tejże kapituły ${ }^{19}$. Wśród radców kurii była inna wybitna postać - ks. Antoni Borowski, który funkcję tę pełnił w latach 19181926. Studia specjalistyczne z zakresu teologii moralnej odbył w Uniwersytecie w Lowanium. Następnie rozpoczął działalność naukową jako wykładowca włocławskiego Seminarium Duchownego, od 1913 r. podjął obowiązki wicerektora, zaś w latach 1918-1925 był rektorem tejże uczelni. Dalszą działalność naukową prowadził na Wydziale Teologii Uniwersytetu Warszawskiego, gdzie wcześniej w 1924 r. obronił rozprawę doktorską, a od 1930 r. był profesorem tej uczelni. W uznaniu zasług w 1921 r. został mianowany kanonikiem włocławskim, w $1937 \mathrm{r}$. kustoszem kapituły, w 1922 r. prałatem papieskim, był też kanonikiem honorowym warszawskim. W latach 1957-1962 pracował jako wykładowca Katolickiego Uniwersytetu Lubelskiego ${ }^{20}$.

Istotną częścią Kurii Biskupiej była kancelaria, którą reprezentowali sekretarze, skarbnik i archiwista, a jej pracami kierował kanclerz. Funkcję tę mógł sprawować kapłan o nieposzlakowanej opinii, odznaczający się wiedzą teologiczną i znajomością prawa kanonicznego. Do jego obowiązków należało spisywanie

${ }^{17}$ K. Rulka, Czapla Piotr, krypt.: P.C. (1868-1928), w: Stownik Polskich Teologów Katolickich 1918-1981 (dalej: SPTK), t. 5, Warszawa 1983, s. 250-251; M. Laszczyk, Profesorowie teologii pastoralnej, w: 425 lat Wyższego Seminarium Duchownego we Włoctawku. Profesorowie i moderatorzy XX wieku, red. W. Hanc, K. Rulka, Włocławek 1997, s. 38-39.

${ }^{18}$ ADW, Akta personalne ks. Rudolfa Filipskiego, sygn. 64, passim; K. Rulka, Filipski Rudolf, krypt.: Ks. R.F. (R.). (1869-1932), SPTK, t. 5, s. 386-388; W. Kujawski, Profesorowie historii (19001908), w: 425 lat Wyższego Seminarium we Włocławku. Profesorowie i moderatorzy XX wieku, red. W. Hanc, K. Rulka, Włocławek 1997, s. 96-97.

${ }^{19}$ Rocznik diecezji włocławskiej 1935, Włocławek 1935, s. 9, 16, 20; K. Rulka, Ks. Wacław Kwarciański (1966-1942), „Kronika Diecezji Włocławskiej” (dalej: KDW), 72 (1989) dod. do nr. 10-11, s. 39-40; J. Dębiński, Duchowieństwo rzymskokatolickie, s. 240, 723.

${ }^{20}$ S. Rosik, Borowski Antoni ks., EK, t. 2, Lublin 1985, kol. 823-824; A. Poniński, Borowski Antoni (1884-1968), SPTK, t. 5, s. 154-158; K. Rulka, Rektorzy, wicerektorzy, prefekci, w: 425 lat Wyższego Seminarium Włoctawku. Profesorowie i moderatorzy XX wieku, red. W. Hanc, K. Rulka, Włocławek 1997, s. 134-135. 
akt, porządkowanie i sporządzanie ich wykazów ${ }^{21}$. Pierwszym kanclerzem kurii był ks. Roman J. Kossowski, który stanowisko to sprawował w latach 1918-1919. Do pełnienia tej funkcji był dobrze przygotowany. Odbył studia specjalistyczne w Akademii Duchownej w Petersburgu, gdzie w 1903 r. uzyskał stopień magistra teologii. W roku 1906 ordynariusz mianował go sekretarzem i obrońcą węzła ma1żeńskiego Konsystorza Włocławskiego. W uznaniu zasług w 1913 r. został mianowany kanonikiem honorowym kaliskim ${ }^{22}$. Kolejnym kanclerzem był ks. Wincenty Gmachowski, który funkcje tę pełnił w latach 1922-1927. Studia specjalistyczne odbył w Fryburgu Szwajcarskim (1913-1915), a następnie w Uniwersytecie Gregoriańskim, gdzie w 1922 r. uzyskał stopień doktora prawa kanonicznego. Wraz z rozpoczęciem pracy kurialnej został wykładowcą włocławskiego Seminarium Duchownego, zaś w dwa lata później został obrońcą węzła małżeńskiego, a od 1927 r. pełnił obowiązki promotora sprawiedliwości. W uznaniu zasług w 1926 r. został mianowany kanonikiem honorowym kaliskim, a następnie obdarzono go godnością szambelana honorowego ${ }^{23}$. W latach 1919-1922 kancelarią kurii kierował wicekanclerz ks. Nikodem Ast. Stanowisko to objął w rok po powrocie ze studiów specjalistycznych w Akademii Duchownej w Petersburgu, gdzie uzyskał stopień magistra prawa kanonicznego. W następnych latach przeszedł do pracy w duszpasterstwie, gdzie został w 1926 r. odznaczony kanonią honorową kaliską ${ }^{24}$.

W dokumencie ustanawiającym skład personalny kancelarii Kurii Biskupiej podano dwa etaty sekretarzy, które nie zostały obsadzone. Jednak jeszcze w $1918 \mathrm{r}$. biskup ustanowił ks. Stefana Petrykowskiego zastępcą sekretarza. W 1922 r. objął on urząd drugiego sekretarza. Dopiero w 1925 r. przeszedł na stanowisko pierwszego sekretarza, zaś drugim sekretarzem został ks. Jacek Pomianowski, który w 1927 r. zrezygnował z funkcji na rzecz pracy w duszpasterstwie ${ }^{25}$. Wśród urzędników kancelarii był skarbnik, którym został ks. Stanisław Pruski. Funkcje tę sprawował w latach 1918-1930. W momencie nominacji na to stanowisko był dyrektorem ekonomicznym włocławskiego Seminarium Duchownego. W uznaniu jego zasług w 1924 r. został mianowany kanonikiem kaliskim, a w 1931 r. został archidiakonem tej kapituły ${ }^{26}$.

${ }^{21} \mathrm{CIC}$, can. $372 \S 1$, can. $373 \S 3$.

${ }^{22}$ Archiwum Archidiecezji Częstochowskiej im. ks. Walentego Patykiewicza w Częstochowie (dalej: AACz), Akta personalne ks. Romana Kossowskiego, sygn. AP 86, passim; W.P. Wlaźlak, Ks. Roman Józef Kossowski (16 II 1875 - 4 IV 1940), „Wiadomości Archidiecezji Częstochowskiej” (dalej: WACz), 80 (2006) nr 3-4, s. 150-151.

${ }^{23}$ S. Librowski, Ofiary zbrodni niemieckiej spośród duchowieństwa diec. włocławskiej, KDW, 41 (1947) nr 7-8, s. 196; B. Cieślak, Profesorowie prawa kanonicznego, w: 425 lat Wyższego Seminarium Duchownego we Włocławku. Profesorowie i moderatorzy XX wieku, red. W. Hanc, K. Rulka, Włocławek 1997, s. 19-20.

${ }^{24}$ ADW, Akta personalne ks. Nikodema Asta, sygn. 5, passim; Diecezja włocławska, s. 175 n; J. Dębiński, Duchowieństwo rzymskokatolickie, s. 178, 240, 763.

${ }^{25}$ ADW, Akta personalne ks. Jacka Pomianowskiego, sygn. 268, passim; J. Dębiński, Duchowieństwo rzymskokatolickie, s. 240.

${ }^{26}$ M. Jaros, Dyrektorzy ekonomiczni (prokuratorzy), w: 425 lat Wyższego Seminarium, s. 154. 
Prawo kanoniczne nakazywało zatrudnienie w kurii archiwariusza, którym w 1918 r. został ks. Stanisław Maternowski ${ }^{27}$. Zapewne z tego powodu skierowano go na studia specjalistyczne w zakresie archiwistyki i dyplomatyki na Uniwersytecie Warszawskim. Dlatego w 1921 r. zastapił go na tym stanowisku ks. J. Pomianowski. Po powrocie ze studiów ks. S. Maternowski w 1927 r. został ponownie archiwariuszem. Swoją działalność naukową zwieńczył w 1933 r., kiedy został doktorem filozofii ${ }^{28}$. Ponadto wśród pracowników kancelarii było dwóch architektów: Jarosław Wojciechowski (1918-1930) oraz Adolf Buraczewski (1924-1939). Pełnili oni funkcje architektów nadzorujących budownictwo sakralne w diecezji ${ }^{29}$.

Oprócz wyżej wzmiankowanych pracowników w kurii, w latach 1918-1925 odnotowano jeszcze proboszczów-konsultorów w osobach księży: Stefana Kulińskiego, Wincentego Matuszewskiego, F. Mikulskiego i Ignacego Zbirchowicza. W tym okresie urzędnikami kurii byli egzaminatorzy prosynodalni, których zatrudniano na innych stanowiskach. Byli wśród nich: ks. A. Borowski, ks. P. Czapla i ks. Józef Kruszyński. Jedynie ks. Bolesław Kunka nie pełnił dotychczas żadnych funkcji w kurii, ale z tego stanowiska odszedł w 1923 r. W kurii powołano także komisję zwaną Consilium vigilantiae, która miała zadanie czuwać nad czystością wiary. W jej skład weszli następujący duchowni: Grzegorz Augustynik (1918-1921), A. Borowski (1918-1925), S. Chodyński (1918-1919), Stanisław Gruchalski (1918-1925), Włodzimierz Jasiński (1918-1925), ks. R.J. Kossowski (1918-1919), W.P. Krynicki (1918-1925), Franciszek Mirecki (19181925), W.S. Owczarek (1918-1925), J.N. Sobczyński (1918-1925), N. Ast (19181925) i Ignacy Zbirochowicz (1919-1925). Biskup ustanowił także sekretarza generalnego do spraw społecznych, którym został ks. Paweł Załuska (1918-1919), a po nim funkcje tę objął ks. Józef Patrzyk. Powołano także sekretarza generalnego do spraw młodzieży w osobie ks. Wincentego Zawadzkiego (1918-1921) i ks. Antoniego Radomskiego (1920-1925). Istotną rolę w zarządzie diecezją spełniała rada administracyjna ustanowiona w 1919 r., w skład której wchodzili kapłani pełniący najważniejsze funkcje w Kurii Diecezjalnej. W omawianym okresie byli to następujący duchowni: A. Borowski, P. Czapla, R. Filipski, W.P. Krynicki, W. Kwarciański, F. Mikulski, W.S. Owczarek i J.N. Sobczyński. Bardzo ważną rolę w diecezji pełnili cenzorzy ksiąg religijnych, którymi w tym czasie byli księża: A. Borowski, Michał Ciesielski, Zenon Cwilong, Antoni Grochowski, J. Kruszyński, Adam Marczewski, Marian Nassalski, J.N. Sobczyński i od 1923 r. Ludwik Wasilkowski ${ }^{30}$.

Z ramienia kurii działała komisja do spraw artystyczno-budowlanych, która nadzorowała wystrój świątyń i stan ich utrzymania. W latach 1918-1925 tworzyli ją księża: Franciszek Buchalski, Władysław Górzyński, Ignacy Kasprzykowski,

${ }^{27}$ S. Zdzitowiecki, Kuria biskupia diecezjalna, KDKK, 12 (1918) nr 12, s. 333; J. Dębiński, Duchowieństwo rzymskokatolickie, s. 240.

${ }^{28}$ ADW, Akta personalne ks. Stanisława Maternowskiego, sygn. 195, passim; J. Dębiński, Duchowieństwo rzymskokatolickie, s. 182, 240.

${ }^{29}$ Tamże, s. 240, 246, 582.

${ }^{30}$ Tamże, s. 240-244. 
Józef Kozakowski i Józef Pełczyński. Istotną rolę w diecezji spełniali wizytatorzy nauki religii, którzy rezydowali w większych ośrodkach miejskich na jej terytorium, gdzie znajdowały się szkoły średnie. We Włocławku wizytatorem nauki religii został ks. W. Kwarciański, którego w 1920 r. zastąpił ks. Antoni Bogdański. W innych ośrodkach miejskich diecezji wizytatorami nauki religii byli: Częstochowa - ks. M. Ciesielski (1918-1925), Pabianice - ks. Tomasz Swinarski (1918-1919), Piotrków [Trybunalski] - ks. W. Jasiński (1918-1925), Radomsko - ks. F. Mirecki (1918-1919), Zduńska Wola - ks. Wojciech Kmieć (1918-1921), ks. Franciszek Ligenza (1921-1923), ks. Jan Hewelke (1923-1925), Kalisz - ks. J.N. Sobczyński (1918-1919), ks. W. Kwarciański (1921-1925). Z nauczaniem religii była powiązana komisja do spraw prasowych i wydawnictw diecezjalnych, w ramach której działali cenzorzy ksiąg religijnych. Należy tutaj podkreślić szczególną rolę powołanej przez biskupa komisji do spraw drukarni i księgarni diecezjalnej. W zarządzie diecezją istotne miejsce zajmowała komisja do spraw bractw i zrzeszeń religijnych, która sprawowała pieczę m.in. nad zakonami męskimi i żeńskimi. Należeli do niej księża: W. Borowski, Z. Cwilong, P. Czapla, W. Jasiński. Komisarzem dla wszystkich zgromadzeń żeńskich został superior jezuitów w Piotrkowie [Trybunalskim] o. Stanisław Lic, a komisarzem dla kół tercjarskich na wikariat częstochowski, był gwardian franciszkanów w Radomsku ${ }^{31}$.

Sporo uwagi ordynariusz poświęcił organistom powołując w tym celu specjalną komisję w 1919 r., której przewodniczył ks. F. Mikulski, a w jej skład weszli duchowni i świeccy ${ }^{32}$. Zajmowała się ona statusem materialnym organistów, czuwała nad ich właściwym przygotowaniem zawodowym w oparciu o regulamin zatwierdzony przez biskupa.

\section{Sąd Biskupi}

Mimo zmian, które przewidywał nowy Kodeks Prawa Kanonicznego w diecezji kujawsko-kaliskiej, nadal ten sam duchowny sprawował urząd wikariusza generalnego w Kurii Biskupiej i oficjała w Trybunale Generalnym lub wiceoficjała w Trybunale Pomocniczym. W chwili utworzenia Sądu Biskupiego w diecezji kujawsko-kaliskiej bp S.K. Zdzitowiecki 20 listopada 1918 r. ustanowił Trybunał Generalny we Włocławku. Na czele Sądu Biskupiego dla całej diecezji, czyli oficjałem został ks. S. Chodyński, zaś wiceoficjałem bp W.S. Owczarek, którego postać szerzej została już omówiona. Ks. S. Chodyński należał do elity intelektualnej włocławskiego duchowieństwa diecezjalnego. Odbył studia specjalistyczne w Akademii Duchownej w Petersburgu, gdzie w 1901 r. nadano mu stopień doktora prawa kanonicznego. W latach 1887-1908 był rektorem włocławskiego Seminarium Duchownego. W tym okresie pracował w Konsystorzu Generalnym we Włocławku jako sędzia surogat, zaś po rezygnacji ze stanowiska rektora seminarium został mianowany oficjałem. Władza diecezjalna ceniła jego kompetencje, dlatego w 1877 r. został kanonikiem włocławskim. W roku 1887 awansował na archidiakona Kapituły Włocławskiej, a w 1894 r. został jej dziekanem.

\footnotetext{
${ }^{31}$ S. Zdzitowiecki, Komisje do spraw poszczególnych, KDKK, 12 (1918) nr 12, s. 334-335.

${ }^{32}$ S. Kuliński, W sprawie związu organistów, KDKK, 13 (1919) nr 10-11, s. 303-304.
} 
W trzy lata później Leon XIII obdarzył go godnością protonotariusza apostolskiego. W wyniku przeprowadzonych zmian został mianowany oficjałem i wikariuszem generalnym. Niestety po kilku miesiącach od tej nominacji, zmarł 16 maja $1919 \mathrm{r}$. we Włocławku ${ }^{33}$. Po nim stanowisko oficjała objął dotychczasowy wiceoficjał bp W.S. Owczarek, który obowiązki te spełniał również po 1925 r., czyli w diecezji włocławskiej ${ }^{34}$.

W akcie erekcyjnym Trybunału Włocławskiego biskup ustanowił pięciu sędziów prosynodalnych w osobach księży: A. Borowskiego, P. Czapli, R. Filipskiego, W. Kwarciańskiego (do 1920 r.) i F. Mikulskiego. Powołano też obrońcę węzła małżeńskiego ks. R.J. Kossowskiego, którego w 1919 r. zastąpił ks. S. Maternowski, zaś w latach 1921-1922 urząd ten sprawował ks. Józef Leśnik. Po kilkunastomiesięcznym wakacie w 1924 r. biskup dokonał nominacji obrońcy węzła małżeńskiego, którym został ks. W. Gmachowski. Wszyscy oni byli zatrudnieni w urzędach kurialnych. Jedynie notariusz ks. Józef Łytkowski, nie był zatrudniony kurii. W roku 1919 zastąpił go ks. N. Ast, pracownik kurii. W analogiczny sposób postąpiono w 1922 r., kiedy funkcję po nim przejął ks. W. Gmachowski $^{35}$. W roku 1924 notariuszem został ks. Stefan Biskupski i spełniał ten urząd do końca omawianego okresu. Był najbardziej wykształconym kapłanem pełniącym te funkcję. Studiował prawo kanoniczne w Uniwersytecie Warszawskim, gdzie w 1932 r. się doktoryzował, w 1937 r. uzyskał habilitację, w 1954 r. został profesorem zwyczajnym. W latach 1953-1956 był wikariuszem kapitulnym diecezji warmińskiej ${ }^{36}$.

Dla odległych południowych krańców diecezji biskup ustanowił Trybunał Pomocniczy w Częstochowie, którego szefem 20 listopada 1918 r. został bp W.P. Krynicki z tytułem wiceoficjała ${ }^{37}$. Do pełnienia tej funkcji był dobrze przygotowany. Studia specjalistyczne odbył w Akademii Duchownej w Petersburgu, gdzie w 1886 r. uzyskał stopień magistra teologii. Po powrocie do diecezji objął obowiązki wykładowcy włocławskiego Seminarium Duchownego. W latach 18901902 był wicerektorem tegoż seminarium. W 1910 r. został mianowany wizytatorem klasztorów diecezji kujawsko-kaliskiej, a w 1914 r. rektorem włocławskiego Seminarium Duchownego. W dniu 29 lipca 1918 r. Benedykt XV mianował go biskupem pomocniczym diecezji kujawsko-kaliskiej. Po ustanowieniu diecezji częstochowskiej w 1925 r. został przeniesiony do Kalisza na równorzędne stanowisko. Po śmierci ordynariusza został wybrany wikariuszem kapitulnym diecezji.

${ }^{33}$ R. Prejs, Administracja diecezjalna w Królestwie Polskim w latach 1864-1918. Studium prozopograficzne, Lublin 2012, s. 123; M. Banaszak, Chodyński Stanisław, krypt.: S.Ch., (1836-1919), SPTK, t. 1, Warszawa 1981, s. 308-314; B. Cieślak, Profesorowie prawa kanonicznego, w: 425 lat Wyższego Seminarium Duchownego we Włocławku. Profesorowie i moderatorzy XX wieku, red. W. Hanc, K. Rulka, Włocławek 1997, s. 17-18.

${ }^{34}$ H. Jabłonowska, Owczarek Wojciech Stanisław, krypt.: W.O., (1875-1938), SPTK, t. 6, Warszawa 1983, s. 597-598.

${ }^{35}$ J. Dębiński, Duchowieństwo rzymskokatolickie, s. 234-235.

${ }^{36}$ K. Rulka, Biskupski Stefan, (1895-1973), SPTK, t. 5, s. 119-124.

${ }^{37}$ S. Zdzitowiecki, Nominacja wiceoficjałów Sądu Biskupiego, KDKK, 12 (1918) nr 12, s. 333. 
W dniu 21 listopada 1927 r. został mianowany biskupem włocławskim. Zmarł 7 grudnia 1928 r. w Warszawie ${ }^{38}$.

W akcie erekcyjnym Trybunału Częstochowskiego ordynariusz ustanowił pięciu sędziów prosynodalnych. Byli to wybitni duchowni wśród nich ks. M. Ciesielski. Odbył studia specjalistyczne w Akademii Duchownej w Petersburgu, gdzie uzyskał w 1899 r. stopień magistra teologii. Za zasługi został odznaczony godnością kanonika kaliskiego w 1918 r., zaś w 1924 r. kustoszem tejże kapituły oraz w 1922 r. prałatem domowym. Był zaangażowany w działalność patriotyczną na Śląsku w czasie plebiscytu. W uznaniu zasług Wojciech Korfanty odznaczył go w 1921 r. Krzyżem na Śląskiej Wstędze Waleczności i Zasługi. W diecezji częstochowskiej był konsultorem diecezjalnym (1926-1934), egzaminatorem prosynodalnym i cenzorem ksiąg religijnych (1926-1934) ${ }^{39}$.

Kapłanem zaangażowanym w działalność sędziego był ks. W. Jasiński, który również odbył studia specjalistyczne w Akademii Duchownej w Petersburgu, gdzie uzyskał w 1913 r. stopień kandydata teologii. W roku 1926 został rektorem Seminarium Duchownego w Łodzi. W dniu 21 sierpnia 1930 r. został mianowany biskupem sandomierskim, zaś 30 września 1934 r. przeniesiony został na stanowisko biskupa łódzkiego. W czasie drugiej wojny światowej został wydalony z diecezji przez władze niemieckie. Z biskupstwa łódzkiego zrezygnował 12 grudnia $1946 \mathrm{r}^{40}$

Innym kapłanem pełniącym funkcję sędziego był ks. F. Mirecki. Odbył on studia specjalistyczne w Akademii Duchownej w Petersburgu, gdzie uzyskał w 1894 r. stopień magistra teologii. Po studiach podjął pracę w Konsystorzu Włocławskim, gdzie był sekretarzem, obrońcą węzła małżeńskiego i regensem. Za zasługi został odznaczony w 1913 r. godnością kanonika kaliskiego, w 1920 r. został kustoszem, a w 1924 r. jej dziekanem. W diecezji częstochowskiej był wikariuszem generalnym (1926-1929) i konsultorem diecezjalnym (1926-1948). W uznaniu zasług w $1927 \mathrm{r}$. został awansowany na prałata domowego ${ }^{41}$.

Sędzią prosynodalnym został także ks. M. Nassalski. Odbył on studia specjalistyczne w Akademii Duchownej w Petersburgu, gdzie uzyskał w 1887 r. stopień magistra teologii. Po powrocie do diecezji został wykładowcą włocławskiego Seminarium Duchownego. W latach 1895-1896 został przez władze carskie zesłany na Syberię. Po powrocie redagował czasopisma katolickie. W roku 1911 został proboszczem parafii św. Barbary w Częstochowie. W uznaniu zasług, w 1919 r. został odznaczony godnością prałata domowego. Po utworzeniu diecezji częstochowskiej pracował na różnych stanowiskach w Kurii Biskupiej. W latach 19261937 był oficjałem Sądu Biskupiego w Częstochowie ${ }^{42}$.

${ }^{38}$ ADW, Akta personalne bp. Władysława Krynickiego, sygn. 161, passim; B. Kawczyński, Krynicki Wtadystaw Pawet, krypt.: Wt.K. (1861-1928), SPTK, t. 6, s. 227-231.

${ }^{39} \mathrm{AACz}$, Akta personalne ks. Michała Ciesielskiego, sygn. AP 22, passim.

${ }^{40}$ K. Dąbrowski, Arcybiskup Włodzimierz Jasiński 1873-1965, Łódź 1990, s. 14 n.

${ }^{41}$ AACz, Akta personalne ks. Franciszka Mireckiego, sygn. AP 129, passim; W.P. Wlaźlak, Ks. Franciszek Mirecki (4 X 1869 - 21 XII 1948), WACz, 79 (2005) nr 9-11, s. 100-101.

${ }^{42}$ K. Rulka, Nassalski Marian, krypt.: Ks. M.N., N. (1860-1942), SPTK, t. 6, s. 529-535. 
Zasłużonym duchownym awansowanym na sędziego prosynodalnego był ks. Bolesław Wróblewski, któremu za działalność patriotyczną władze carskie zakazały pracy duszpasterskiej. W odrodzonej Polsce był posłem do Sejmu. Za zasługi dla diecezji w 1917 r. został odznaczony kanonią honorową kaliską, w 1924 r. godnością prałata domowego, a w 1949 r. awansowany na protonotariusza apostolskiego. Ponadto był kanonikiem honorowym lubelskim. W diecezji częstochowskiej był konsultorem diecezjalnym ${ }^{43}$.

Do sędziów prosynodalnych w 1921 r. dołączył ks. A. Grochowski, który po święceniach kapłańskich pracował w duszpasterstwie, szkolnictwie oraz w Konsystorzu Piotrkowskim, gdzie w latach 1894-1916 był asesorem. W diecezji częstochowskiej był konsultorem diecezjalnym, egzaminatorem prosynodalnym, sędzią prosynodalnym i cenzorem ksiąg religijnych. Za gorliwą działalność kapłańską został odznaczony kanonią honorową kaliską i kanonią honorową łódzką ${ }^{44}$.

W Trybunale Częstochowskim oprócz wymienionych sędziów prosynodalnych, pracował także obrońca węzła małżeńskiego, którym w 1918 r. został ks. J. Leśnik. Po trzech latach pracy na tym stanowisku został przeniesiony do Trybunału Włocławskiego na analogiczne stanowisko. Z funkcji tej zrezygnował w 1922 r., gdyż został wykładowcą włocławskiego Seminarium Duchownego. Do wspomnianych obowiązków był dobrze przygotowany, gdyż odbył studia specjalistyczne w Akademii Duchownej w Petersburgu, które ukończył uzyskaniem w 1913 r. stopnia magistra teologii. Za zasługi dla diecezji został odznaczony w 1926 r. godnością szambelana honorowego ${ }^{45}$. Po jego odejściu z Trybunału Częstochowskiego od 1921 r. obowiązki te spełniał ks. Tadeusz Peche ${ }^{46}$. Po nim w 1923 r. na tym stanowisku pracował ks. Karol Makowski, który w rok przed objęciem tego stanowiska uzyskał stopień doktora teologii w Uniwersytecie św. Tomasza w Rzymie ${ }^{47}$. Był on ostatnim na tym stanowisku przed utworzeniem diecezji częstochowskiej. W trybunale pracował jeszcze notariusz, którym został ks. W. Gmachowski ${ }^{48}$. W roku 1922 zastąpił go ks. Bronisław Kochanowicz ${ }^{49}$, po którym w rok później obowiązki przejął ks. Wojciech Mondry. Pracował on do końca omawianego okresu ${ }^{50}$.

${ }^{43} \mathrm{AACz}$, Akta personalne ks. Bolesława Wróblewskiego, sygn. AP 226, passim.

${ }^{44} \mathrm{AACz}$, Akta personalne ks. Antoniego Grochowskiego, sygn. AP 51, passim; W. Patykiewicz, Ks. Antoni Grochowski (1860-1937), „Częstochowskie Wiadomości Diecezjalne”, 38 (1964) nr 9, s. 204.

${ }^{45}$ J. Dębiński, Duchowieństwo rzymskokatolickie, s. 236 n.

${ }^{46}$ AACz, Akta personalne ks. Tadeusza Peche, sygn. AP 157, passim; J. Dębiński, Duchowieństwo rzymskokatolickie, s. 236.

${ }^{47} \mathrm{AACz}$, Akta personalne ks. Karola Makowskiego, sygn. AP 116, passim; J. Dębiński, Duchowieństwo rzymskokatolickie, s. $182 \mathrm{n}$.

${ }^{48} \mathrm{ADW}$, Akta personalne ks. Wincentego Gmachowskiego, sygn. 77, passim; J. Dębiński, Duchowieństwo rzymskokatolickie, s. 236.

${ }^{49}$ Tamże, s. 236.

${ }^{50} \mathrm{AACz}$, Akta personalne ks. Wojciecha Mondrego, sygn. AP 300, passim; J. Dębiński, Duchowieństwo rzymskokatolickie, s. 236. 
Obok Trybunału Generalnego w stolicy diecezji oraz podległego mu Trybunału Częstochowskiego ordynariusz ustanowił Trybunał Pomocniczy w Kaliszu. Na jego czele stanął ks. J.N. Sobczyński z tytułem wiceoficjała. Od roku 1887 został wykładowcą włocławskiego Seminarium Duchownego, zaś od 1894 r. był notariuszem Konsystorza Włocławskiego. W roku 1901 zrezygnował z dotychczasowych stanowisk i przeniósł się na probostwo do Kalisza. Jednocześnie podjął obowiązki sędziego surogota w Konsystorzu Kaliskim, zaś w 1905 r. został jego oficjałem. W roku 1918 po zmianach w prawie kanonicznym został wiceoficjałem Trybunału Kaliskiego i piastował ten urząd do 1925 r., a następnie w latach 1927-1929, kiedy ostatecznie uległ on likwidacji. Był cenionym za pracę na dotychczasowych stanowiskach, dlatego w 1898 r. został mianowany kanonikiem honorowym, w 1910 r. kanonikiem kaliskim, w 1913 r. kustoszem, w 1919 r. dziekanem, a w 1924 r. archidiakonem i ostatecznie w 1926 r. prepozytem tej kapituły. Nadto w 1930 r. został odznaczony godnością prałata domowego ${ }^{51}$.

W akcie erekcyjnym Trybunału Kaliskiego biskup ustanowił dwóch sędziów prosynodalnych. Pierwszym był ks. Adam Marczewski, który stanowisko to piastował do 1929 r. Był absolwentem Uniwersytetu Gregoriańskiego, gdzie uzyskał stopień doktora teologii. W uznaniu zasług w 1919 r. został kanonikiem kaliskim, w 1926 r. dziekanem tejże kapituły. Drugim sędzią prosynodalnym został ks. Ignacy Płoszaj, który stanowisko to piastował do 1925 r. Do pracy tej był dobrze przygotowany, gdyż wcześniej pracował w Konsystorzu Kaliskim na stanowisku sędziego surogata. Jego kompetencje dostrzegły władze kościelne, które w 1899 r. mianowały go prepozytem Kapituły Kaliskiej i prałatem domowym.

Wraz z sędziami prosynodalnymi, ustanowiono obrońcę węzła małżeńskiego. Został nim ks. Zenon Kalinowski, który stanowisko to piastował do $1929 \mathrm{r}$. W uznaniu zasług w 1924 r. odznaczono go tajną szambelanią, w 1931 r. został kanonikiem kaliskim. W trybunale był jeszcze zatrudniony notariusz ks. Stanisław Masłowski, którego w 1919 r. zastąpił ks. Józef Michałowski. Z kolei w 1921 r. zastąpił go ks. Tadeusz Rutkowski, na którego miejsce w 1923 r. został powołany ks. Władysław Zabłocki. Funkcje tę sprawował do końca omawianego okresu ${ }^{52}$.

\section{Podsumowanie}

Po wprowadzeniu w życie nowego Kodeks Prawa Kanonicznego w 1918 r. biskup kujawsko-kaliski ustanowił Kurię Biskupią we Włocławku, dla prowadzenia spraw administracyjnych diecezji. Z kolei dla prowadzenia spraw sądowych ustanowił Sąd Biskupi, czyli Trybunał Generalny we Włocławsku oraz Trybunał Pomocniczy w Częstochowie i Trybunał Pomocniczy w Kaliszu. Określił ponadto podległość terytorialną. W miejsce dawnego oficjalatu włocławskiego ustanowił wikariat generalny włocławski. Dawny oficjalat piotrkowski został przemiano-

${ }^{51}$ ADW, Akta personalne ks. Jana Sobczyńskiego, sygn. 310, passim; S. Librowski, Ksiądz Jan Nepomucen Sobczyński (1861-1942), „Archiwa, Biblioteki i Muzea Kościelne”, 2 (1961) z. 1-2, s. 323-330; W. Kujawski, Sobczyński Jan Nepomucen (1861-1942), SPTK, t. 7, Warszawa 1983, s. $141-142$.

${ }^{52}$ J. Dębiński, Duchowieństwo rzymskokatolickie, s. 236 n. 
wany na wikariat częstochowski, do którego przyłączono dekanaty powiatu wieluńskiego. Te ostatnie dotychczas wchodziły w skład oficjalatu kaliskiego, który pomniejszony o nie nazywano teraz wikariatem kaliskim. Pomimo iż miano oddzielić władzę administracyjną od sądowniczej, to jednak ten sam duchowny kierował pracami kurii i sądu. W stolicy diecezji rezydował wikariusz generalny dla całej diecezji bp W.S. Owczarek oraz ks. S. Chodyński, któremu podlegał wikariat włocławski. Ksiądz S. Chodyński został nadto mianowany oficjałem Trybunału Włocławskiego, który sprawował pieczę nad całą diecezją. Jego zastępcą, czyli wiceoficjałem dla całej diecezji został bp W.S. Owczarek, który po śmierci ks. S. Chodyńskiego objął urząd oficjała. Wikariuszem generalnym i wiceoficjałem w Trybunale Częstochowskim został bp W.P. Krynicki. Z kolei wikariuszem generalnym i wiceoficjałem w Trybunale Kaliskim został mianowany ks. J.N. Sobczyński. Ten skład obsady personalnej utrzymał się do 1925 r., kiedy na południowym terytorium diecezji kujawsko-kaliskiej nazywaną od tego momentu włocławską, została utworzona diecezja częstochowska. Biskup W.P. Krynicki przeniósł się do Kalisza na równorzędne stanowisko, zaś podlegli mu dotychczas pracownicy zostali pracownikami instytucji diecezjalnych w Częstochowie.

Należy zauważyć, że analogicznie jak to było w przypadku wikariuszy generalnych i oficjałów, których urzędy piastowała ta sama osoba, tak było w przypadku podległych im pracownikom. W kurii pracowali kanclerz, konsultorzy, radcowie, sekretarze, skarbnik, archiwariusz, architekci oraz członkowie różnych komisji, cenzorzy ksiąg religijnych i wizytatorzy nauki religii. Zatrudnieni na tych stanowiskach duchowni pracowali również $\mathrm{w}$ sądzie, jako sędziowie prosynodalni, obrońcy węzła małżeńskiego i notariusze. Warto podkreślić, że większość księży zatrudnionych we wspomnianych instytucjach stanowiła elitę duchowieństwa diecezji. Ukończyli oni studia specjalistyczne w zagranicznych uczelniach, gdzie uzyskali stopnie naukowe. Swoje obowiązki spełniali gorliwie, gdyż władze kościelne odznaczyły ich godnościami kapitulnymi w diecezji oraz papieskimi. Wielu z nich pozostawiło po sobie znaczący dorobek naukowy i zrobiło karierę akademicką.

\section{REFERENCES / BIBLIOGRAFIA}

\section{Źródła}

Archiwum Archidiecezji Częstochowskiej im. ks. Walentego Patykiewicza

w Częstochowie (AACz)

sygn. AP 22, Akta personalne ks. Michała Ciesielskiego

sygn. AP 51, Akta personalne ks. Antoniego Grochowskiego

sygn. AP 86, Akta personalne ks. Romana Kossowskiego

sygn. AP 116, Akta personalne ks. Karola Makowskiego

sygn. AP 129, Akta personalne ks. Franciszka Mireckiego

sygn. AP 157, Akta personalne ks. Tadeusza Peche

sygn. AP 22, Akta personalne ks. Bolesława Wróblewskiego

sygn. AP 300, Akta personalne ks. Wojciecha Mondrego 
Archiwum Diecezji Włocławskiej (ADWł.)

sygn. 5, Akta personalne ks. Nikodema Asta

sygn. 64, Akta personalne ks. Rudolfa Filipskiego

sygn. 77, Akta personalne ks. Wincentego Gmachowskiego

sygn. 161, Akta personalne bp. Władysława Krynickiego

sygn. 195, Akta personalne ks. Stanisława Maternowskiego

sygn. 238a, Akta personalne bp. Wojciecha Owczarka, t. 1-2

sygn. 268, Akta personalne ks. Jacka Pomianowskiego

sygn. 310, Akta personalne ks. Jana Sobczyńskiego

Bulla Vixdum Poloniae unitas, „Acta Apostolicae Sedis”, 17 (1925) s. 521-528.

Catalogus ecclesiarum et utriusque cleri, tam saecularis quam regularis, dioecesis Vladislaviensis seu Calissiensis pro anno Domini 1919, Wladislaviae 1919.

Catalogus ecclesiarum et utriusque cleri, tam saecularis quam regularis, dioecesi Vladislaviensis seu Calissiensis pro anno Domini 1923, Wladislaviae 1923.

Catalogus ecclesiarum et utriusque cleri, tam saecularis quam regularis, dioecesis Vladislaviensis seu Calissiensis pro anno Domini 1924, Wladislaviae 1924.

Codex Iuris Canonici. Pii X Pontificis Maximi iussu digestus. Benedicti Papae XV auctoritate promulgatus, red. P. Gasparri, Romae 1934.

Diecezja włocławska 2000, Włocławek 2001.

Rocznik diecezji włocławskiej 1935, Włocławek 1935.

Zdzitowiecki S., Komisje do spraw poszczególnych, „Kronika Diecezji Kujawsko-Kaliskiej", 12 (1918) nr 12, s. 334-335.

Zdzitowiecki S., Kuria Biskupia Diecezjalna, „Kronika Diecezji Kujawsko-Kaliskiej”, 12 (1918) nr 12, s. 333.

Zdzitowiecki S., Nominacja wiceoficjałów Sądu Biskupiego, „,Kronika Diecezji Kujawsko-Kaliskiej”, 12 (1918) nr 12, s. 332-333.

Zdzitowiecki S., Nominacja wikariuszów generalnych, „Kronika Diecezji Kujawsko-Kaliskiej”, 12 (1918) nr 12, s. 331-332.

\section{Opracowania}

Banaszak M., Chodyński Stanisław, krypt.: S.Ch., (1836-1919), w: Stownik Polskich Teologów Katolickich, t. 1, red. H.E. Wyczawski, Warszawa 1981, s. 308-314.

Cieślak B., Profesorowie prawa kanonicznego, w: 425 lat Wyższego Seminarium Duchownego we Włocławku. Profesorowie i moderatorzy XX wieku, red. W. Hanc, K. Rulka, Włocławek 1997, s. 17-26.

Dąbrowski K., Arcybiskup Włodzimierz Jasiński 1873-1965, Łódź 1990.

Dębiński J., Duchowieństwo rzymskokatolickie diecezji włocławskiej w latach 1918-1939, Toruń 2010.

Jabłonowska H., Owczarek Wojciech Stanisław, krypt.: W.O., (1875-1938), w: Słownik Polskich Teologów Katolickich, t. 6, red. H.E. Wyczawski, Warszawa 1983, s. $597-$ 598.

Jaros M., Dyrektorzy ekonomiczni (prokuratorzy), w: 425 lat Wyższego Seminarium Duchownego we Włoctawku. Profesorowie i moderatorzy XX wieku, red. W. Hanc, K. Rulka, Włocławek 1997, s. 153-158.

Kawczyński B., Krynicki Władysław Paweł, krypt.: Wt.K. (1861-1928), w: Słownik Polskich Teologów Katolickich, t. 6, red. H.E. Wyczawski, Warszawa 1983, s. 227-231.

Kujawski W., Profesorowie historii (1900-1908), w: 425 lat Wyższego Seminarium Duchownego we Włocławku. Profesorowie $i$ moderatorzy XX wieku, red. W. Hanc, K. Rulka, Włocławek 1997, s. 95-100. 
Kujawski W., Sobczyński Jan Nepomucen (1861-1942), w: Słownik Polskich Teologów Katolickich, t. 7, red. H.E. Wyczawski, Warszawa 1983, s. 141-142.

Kuliński S., W sprawie związku organistów, „Kronika Diecezji Kujawsko-Kaliskiej”, 13 (1919) nr 10-11, s. 303-304.

Librowski S., Chodyński Stanisław ks., w: Encyklopedia katolicka, t. 3, red. F. Gryglewicz, Lublin 1985, kol. 207-208.

Librowski S., Ksiądz Jan Nepomucen Sobczyński (1861-1942), „Archiwa, Biblioteki i Muzea Kościelne", 2 (1961) z. 1-2, s. 323-330.

Librowski S., Ofiary zbrodni niemieckiej spośród duchowieństwa diec. włocławskiej, „,Kronika Diecezji Włocławskiej”, 41 (1947) nr 7-8, s. 184-208.

Łaszczyk M., Profesorowie teologii pastoralnej, w: 425 lat Wyższego Seminarium Duchownego we Włocławku. Profesorowie i moderatorzy XX wieku, red. W. Hanc, K. Rulka, Włocławek 1997, s. 34-42.

Patykiewicz W., Ks. Antoni Grochowski (1860-1937), „Częstochowskie Wiadomości Diecezjalne", 38 (1964) nr 9, s. 204.

Poniński A., Borowski Antoni (1884-1968), w: Słownik Polskich Teologów Katolickich, t. 5, red. H.E. Wyczawski, Warszawa 1983, s. 154-158.

Prejs R., Administracja diecezjalna $w$ Królestwie Polskim w latach 1864-1918. Studium prozopograficzne, Lublin 2012.

Rosik S., Borowski Antoni ks., w: Encyklopedia Katolicka, t. 2, red. F. Gryglewicz, Lublin 1985, kol. 823-824.

Rulka K., Biskupski Stefan, (1895-1973), w: Słownik Polskich Teologów Katolickich, t. 5, red. H.E. Wyczawski, Warszawa 1983, s. 119-124.

Rulka K., Czapla Piotr, krypt.: P.C. (1868-1928), w: Stownik Polskich Teologów Katolickich, t. 5, red. H.E. Wyczawski, Warszawa 1983, s. 250-251.

Rulka K., Filipski Rudolf, krypt.: Ks. R.F. (R.). (1869-1932), w: Stownik Polskich Teologów Katolickich, t. 5, red. H.E. Wyczawski, Warszawa 1983, s. 386-388.

Rulka K., Nassalski Marian, krypt.: Ks. M.N., N. (1860-1942), w: Stownik Polskich Teologów Katolickich, t. 6, red. H.E. Wyczawski, Warszawa 1983, s. 529-535.

Rulka K., Owczarek Wojciech Stanisław bp, w: Encyklopedia katolicka, t. 14, red. E. Gigilewicz, Lublin 2010, kol. 1048-1049.

Rulka K., Rektorzy, wicerektorzy, prefekci, w: 425 lat Wyższego Seminarium Duchownego we Włocławku. Profesorowie i moderatorzy XX wieku, red. W. Hanc, K. Rulka, Włocławek 1997, s. 132-142.

Szymak J., Ś.p. ks. Feliks Mikulski, „,Kronika Diecezji Kujawsko-Kaliskiej”, 37 (1933) nr 6, s. 181-184.

Wlaźlak W., Judicium Succursale Czenstochoviensis (1918-1925), „Gubernaculum et Administratio. Zeszyty Naukowe Instytutu Administracji Wyższej Szkoły Pedagogicznej w Częstochowie", (2002) z. 2, s. 7-17.

Wlaźlak W., Sąownictwo kościelne w diecezji włocławskiej czyli kaliskiej (1819-1918), „Czasopismo Prawno-Historyczne”, 54 (2002) z. 1, s. 365-385.

Wlaźlak W.P., Ks. Franciszek Mirecki (4 X 1869 - 21 XII 1948), „Wiadomości Archidiecezji Częstochowskiej”, 79 (2005) nr 9-11, s. 100-101.

Wlaźlak W.P., Ks. Roman Józef Kossowski (16 II 1875 - 4 IV 1940), „Wiadomości Archidiecezji Częstochowskiej”, 80 (2006) nr 3-4, s. 150-151.

Włodarczyk T., Konkordaty. Zarys historii z uwzględnieniem XX wieku, wyd. 2, Warszawa 1986. 


\title{
PERSONNEL CHANGES IN THE ORGANIZATION \\ OF ADMINISTRATION AND JUDICIARY \\ OF THE KUYAVIA-KALISZ DIOCESE (1918-1925)
}

\begin{abstract}
The issue of personnel changes in the administration and judiciary of the Kuyavia-Kalisz Diocese between 1918 and 1925 was determined by several factors. First of all, there were changes in the church legislation. The new Code of Canon Law, which came into force in 1918, separated the administrative and judicial authorities. It was then that the Bishop of Kuyavia and Kalisz established the Bishop's Curia in Włocławek to handle administrative matters, and the General Tribunal in Włocławek and the Auxiliary Tribunal in Częstochowa and Kalisz to handle court cases. He established the General Vicariate of Wloclawek, the Officiality of Kalisz became the Vicariate, and the Officiality of Piotrków was renamed to the Vicariate of Częstochowa. The Vicar General for the whole diocese, which was also an auxiliary bishop, resided in Włocławek. Moreover, in the capital of the diocese, Rev. S. Chodyński, to whom the Vicariate of Włocławek was subordinate, was also a judicial vicar of the Włocławek Tribunal. The adjutant judicial vicar of this Court was Bishop W. S. Owczarek, who then took the office of judicial vicar. Bishop W. P. Krynicki became the Vicar General and the adjutant judicial vicar of the Częstochowa Tribunal, while Rev. J. N. Sobczyński was the Vicar General and the adjutant judicial vicar of the Kalisz Tribunal. It should be noted that the Curia employed a chancellor, consultants, counsellors, secretaries, a treasurer, an archivist, architects, members of various commissions, censors of religious books and catechesis visitors. The clergymen holding the above positions also worked in court, and most of them constituted an elite among the clergy, well educated in foreign universities. The diocesan authority appreciated their commitment, which was reflected in the ecclesiastical positions they were given. This composition of the staff changed in 1925, when the Kuyavia-Kalisz Diocese lost the Częstochowa Vicariate to a newly established diocese.
\end{abstract}

Keywords: Kuyavia-Kalisz Diocese; Włocławek; Włocławek Diocese; curia chancellor; consistory; bishop's curia; bishop's court 